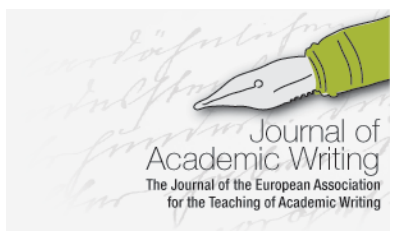

Journal of Academic Writing Vol. 8 No 2 Winter 2018 pages 191-201 http://dx.doi.org/10.18552/joaw.v8i2.437

\title{
How Tutors of Academic Writing Can Use the Theory of Transfer of Learning
}

Bonnie Devet

College of Charleston, USA

\begin{abstract}
One of the goals for tutors of academic writing is to help student writers tailor their writing processes to different writing projects so that students adapt what they know about one type of writing to another. This ability to write in different contexts can be explained by the theory of transfer of learning, which is generally defined as the ability to take something learned in one context and adapt, apply, or remix knowledge or skills in new contexts, including educational, civic, personal, or professional (Driscoll 2011). The mind, seeing similarities to what is already known, extends what is similar to another activity (Haskell 2001: 11). Tutors of writing need to know about transfer. Six categories of transfer - content, context, genres, writers' prior knowledge, students' ability to reflect, and dispositions - offer a lens to help researchers, trainers of tutors, or tutors (whether of L1 or L2 writers) to better identify where and how transfer could happen so that tutors are more prepared to look for opportunities to tutor for transfer. This paper offers insights into how these categories help tutors of academic writing who want to enhance students' acquisition of academic skills.
\end{abstract}

\section{Introduction}

Working one-to-one with student writers is a challenging, often difficult task. Students bring to their tutoring sessions their backgrounds as writers and their assumptions about the writing process as well as their dispositions about the assignment, the act of writing itself, and even their identities as writers. All these factors are in play when tutors of academic writing assist students. Of the many goals of a tutorial, a prime one is helping students see how what they already know about one type of writing can help when writing in another context.

This ability to write in different contexts can be understood through the theory of transfer of learning. 'Transfer' or 'writing knowledge transformation' (Donahue 2016: 109) is generally defined as the ability to take something learned in one context and adapt, apply, or remix knowledge or skills in new contexts, including educational, civic, personal, or professional (Driscoll 2011). The mind, seeing similarities to what is already known, extends what is similar to another activity (Haskell 2001: 11). Simply put: if you can drive a car, you can probably learn to drive a truck. A previously learned concept is applied 'to [a] greater or lesser effect in a subsequent context' (Leonard and Nowacek 2016: 259).

We engage in transfer all the time, with our mind seeking out similarities. Some connections are close to the source target, or 'near transfer' (Perkins and Salomon 1988), as when an academic tutor points out to a student writer how similar sentences both need semicolons. Other connections are created through 'far transfer' (Perkins and Salomon 1988), where the contexts are not so evident. Picnickers who forget to bring a knife to slice their cake might use a credit card instead (Haskell 2001: 30). This activity of making connections - both near and far - is the basis for transfer. 
Transfer theory is an essential tool for tutors of academic writing. It provides a way to understand what is transpiring during tutorials so that student writers can be 'cued, primed, and guided' to make connections (Perkins and Salomon 1989: 19). As Doug Brent (2011) argues in his well-known essay 'Transfer, Transformation, and Rhetorical Knowledge: Insights from Transfer Theory,' transfer 'emphasiz[es] [...] learning fundamental principles, on being mindful, on explicitly cuing learners to help them make connections that might otherwise elude them and on mentoring and providing scaffolding to help them survive the shock of boundary crossing' (2011: 416). This paper, then, offers insight into the value of transfer for tutors who want to enhance students' acquisition of academic skills, by providing six categories of transfer - content, context, genres, writers' prior knowledge, students' ability to reflect, and dispositions - that serve as a lens to help trainers and tutors (whether of L1 or L2 writers) to identify better how transfer can be fostered.

\section{European and American Scholars on Transfer}

Transfer theory is not new to the teaching of writing. Since the 1920s, according to Christiane Donahue's 'Writing and Global Transfer Narratives: Situating the Knowledge Transformation Conversation,' the term "transfer" has been present in Writing Studies scholarship. It is only more recently, in the 1990s, that European and American researchers have been investigating the concept, though perhaps not always under the label of transfer (Donahue 2016: 109, 110). Finnish researchers Terttu Tuomi-Gröhn and Yrjö Engeström (2003), for example, have focused on cultural-historical activity (CHAT), more often called "activity theory," to explain how students move from one discipline's writing to another. When students enter the "system" of writing a history paper, for instance, they become part of an environment shaped by 'cultural means, tools, and signs' (Elon College 2015). So, they need to learn tools, like what language to use as they write an historical analysis. As students enter such a system, they must also investigate the context for their writing; that is, they must discover what is similar to what they already know and what is different (Devet 2015: 130). The Swiss scholar Phillippe Perrenoud has explored this role of context, noting it can hinder transfer, such as when students do not recognize what has already been learned in another course applies to the current one (Donahue 2016: 110-111). From another angle, the French researcher Ghysian Samson has looked into the effect of metacognitive functions on transfer, emphasizing that for transfer to occur, learners must be aware of their own knowledge-making capabilities (Donahue 2016: 111). Knowing what one knows about writing in one genre, for instance, helps writers craft a document in a new genre. Without such awareness, there may be no transfer.

In the US, scholars have also been studying transfer, looking at the topic through the field of Educational Psychology, which has examined cognitive processes. The earliest work of Educational Psychologists dates from 1901, with Edward Thorndike and Robert S. Woodworth explaining how the mind functions as it seeks connections. Building on Thorndike and Woodworth's work, cognitive theorists (e.g., Bransford, Brown, Cocking 2000, Haskell 2001, Leberman, McDonald and Doyle 2006, Perkins and Salomon 1988, 1989, 2012) also characterize the mechanics of transfer. David Perkins and Gavriel Salomon (1988), for example, famously discuss "low road" transfer, where the connections between contexts is so alike that it triggers an automatic response ("Teaching"). This semi-automatic reaction is exhibited when workers follow the same procedure, like academic tutors beginning every tutoring session by asking student writers the same questions: 'Who is your professor, and what is the assignment?' Opposite to low road is "high road" transfer: the mind engages in deliberate, mindful abstraction to determine patterns and principles that underlie the new context. From many examples, the mind extrapolates general concepts. Experienced tutors, after conducting several successful sessions, often step back to ascertain which strategies can be applied to subsequent tutorials. An experienced tutor in my center said she found in her many sessions that using figurative language to explain concepts was valuable. So, when she encounters students who only want to add commas to their sentences instead of, first, looking at ideas, she explains to them: 'Focus on the head wounds instead of the knee scrapes' (Goodlett 2001: 15). Through high road transfer, she has decided figurative language is useful for her tutoring toolbox. 


\section{Writing Studies, Writing Centers, and Transfer}

Although Educational Psychology has provided a cognitive foundation for understanding transfer, cognition by itself is not sufficient to account for transfer (Wardle 2007: 67). The field of Writing Studies has expanded on Educational Psychology's work. In fact, for over twenty years, Writing Studies has been exploring transfer (Devet 2015: 128). With such an extensive research period, I find it convenient to organize the scholarship into six categories, based on the researchers' emphasis: content, prior knowledge, dispositions, reflection, context, and genres (Devet 2015: 128). Although any categories are only conveniences and can overlap, I have found, without these categories, transfer of learning can seem overwhelming and, thus, not necessarily useful to trainers and tutors of academic writing. However, these categories offer a means for researchers, trainers of tutors, and tutors to categorize better where and how transfer is happening or could happen during tutorials. They could even be future ways to train tutors. So, I will explain each category, with writing center examples, to show how trainers and tutors are in key positions to trigger the learning of writers.

Please note that all observations reported in this paper are based on anonymous comments from students on end-of-term evaluations of the writing center. Examples are also taken from informal observations I made while in the writing center itself, sitting off to the side of sessions, over a two-year period. Oral permission was granted by students and tutors themselves to recount the observations, with anonymity.

The first category can be classified as the content scholars (Beaufort 2012, Bergmann and Zepernik 2007, Carroll 2002, Downs and Wardle 2007, Center for Engaged Learning 2013, Russell 1995, Smit 2007, Wardle 2007, Yancey, Robertson and Taczak 2014). These researchers stress that tutors may use rhetorical principles, such as thesis, claims, audience, purpose, examples as evidence, when discussing all writings, so student writers can begin to understand that these are 'key concepts about writing, abstract principles that transcend writing situations' (Hill 2016: 79). Although student writers may not be familiar with every rhetorical concept, tutors can define and use the principles, pointing out how students' papers exemplify them. For instance, a tutor was trying to explain how to use examples in an argument; she told the student that she uses this rhetorical feature in her own writing: 'I announce the example, describe it, and then explain how it works as an illustration.' Then, the tutor fostered transfer by saying, 'Now, where could you use this technique in your own paper?' Using herself as a model, the tutor invited the student writer to engage in transfer. Such an approach works well in writing centers because tutors as role models can encourage student writers to look for these same rhetorical principles in each piece of writing, no matter the topic or discipline.

Other scholars focus on the writing experience students bring to college, that is, prior knowledge, in order to determine how these experiences affect transfer (Beaufort 2012, Bergmann and Zepernik 2007, Cleary 2013, Hill 2016, Nowacek 2011, Reiff and Bawarshi 2011, Center for Engaged Learning 2013, Rounsaville 2012, Rounsaville, Goldberg and Bawarshi 2008, Yancey 2009, Yancey, Robertson and Taczak 2014). As Heather Hill explains, 'If students learn something in one situation and then go into another situation that they see as similar, they will be likely to draw on that previous knowledge to help them complete the task in the new situation' (2016: 80). The scholarship examines several areas, including the 'writing processes' students bring to college, their extracurricular writing (writing a column for a school newspaper), 'absent prior knowledge' (when students come to college not knowing something they need to know), 'points of departure' (how testing and grades affect the student's view of writing), 'beliefs' about the writing process itself, including misconceptions that good writers are born, and anxiety about writing (Yancey, Robertson and Taczak 2014).

Tapping into students' prior knowledge helps tutors cultivate transfer. They can ask students what other writings the current assignment reminds them of (Carroll 2002: 95) and 'what prior resources they might be able to draw on or need to adapt in order to complete the assignment' (Rousanville, Goldberg and Bawarshi 2008: 108). They can also ask students what other writings they have done for the professor, and what they learned about writing that piece that they can apply here (Cardinal 2018: 8). Tutors can also be trained to use students' prior 
knowledge by engaging in 'not talk', that is, what is not required by the assignment: 'It's not an analysis, but it is an argument' (Nowacek 2011: 117-121). For instance, a student who had written many papers in her English courses was writing a report on plant productivity for Biology. The tutor encouraged 'not talk' by asking the student how the Biology report was not an English term paper. The student said English papers are different because they usually offer a personal view of a poem or novel, using MLA citations. Biology reports are not English papers since they present research in the scientific pattern of Introduction, Methods, Results, and Discussion (IMRAD) (Bates College 2017), with APA citations. By tapping into the student's prior knowledge and employing the pedagogical technique of describing what the writing was not, the tutor may help the writer see connections between a current assignment and a prior one. In fact, tutors have an advantage over classroom instructors: because tutors can tap into their experiences working with other writers, they can help students see connections from prior writings even more than can instructors who may be more focused on one discipline.

Overlapping with prior knowledge is another approach to transfer: reflection. Scholars (Ambrose et al. 2010, Beaufort 2012, Brent 2011, Hall 2017, Hill 2016, Nelms and Dively 2007, Reiff and Bawarshi 2011, Wardle 2007, Yancey 2009, Yancey, Robertson and Taczak 2014) argue students need to think about their learning so that they are 'better able to remember and draw on that learning when they get into new situations' (Hill 2016: 82). Heavily influenced by Educational Psychology, these scholars believe students become rhetorically aware by engaging in high road transfer, that is, abstracting principles and being mindful so that they can articulate their own writing processes. Tutors may encourage writers to step back from the current assignment by asking students to think about what the students have learned by completing it. For example, a tutor asked a student what she had learned about writing a Biology lab report. Engaging the student in metacognitive reflection helped the student see a lab report was one genre while an English term paper was another. At the end of the tutorial, the tutors can stress the 'carry away' by asking students how they will apply what they learned to their next writings (Cardinal 2018: 8). Performing such an overview lets students draw on what they have learned when they write another document (Hill 2016: 82). After reflecting, the student commented, 'The person that helped me asked questions as to why I wrote what I wrote. I am now more aware of various writing styles.'

Dispositions refers to the habits of mind student writers bring to their tasks. Some writers may be reluctant to let go of previously learned concepts: they are the 'boundary guarders' (Reiff and Bawarshi 2011: 314), like the writers who apply a five-paragraph formula to all writings. Even more extreme are the 'defended learners' (Cousins 2006: 141), who see the changes as challenging their very selves. Without a willingness to learn, these writers may not engage in transfer. Other dispositions that affect transfer are 'value, self-efficacy, attribution, and selfregulation' (Driscoll and Wells 2012). When students see the "value" or how what they are learning is useful, they are more likely to engage in transfer. Also, how student writers feel about themselves as writers ("self-efficacy") may affect their willingness to transfer what they know to the task at hand. Tutors need to reassure writers; otherwise, writers who feel they cannot possibly write a History term paper will not be able to tap into their writing knowledge from other rhetorical situations to use for the current assignment. Another vital disposition is how writers assign causes to specific events or outcomes (called "attribution"). If writers think they have received an "A" because of their own hard work, they are more open to transfer. Another habit of mind necessary for tutors to promote is self-regulation: the ability to set goals and manage choices. Tutors can foster this disposition by asking what aspect of the writing the students want to work on first so writers feel like captains of a ship, not merely crew members. Tutors as coaches, not evaluators of writing like instructors, are well situated to help students develop beneficial habits of mind, or as one student stated, 'I am not afraid of my writing anymore.'

Besides content, prior knowledge, reflection, and dispositions, scholars have also examined the role of context in transfer. This type of transfer refers to the system in which writers find themselves. When composing emails, students make rhetorical choices, such as adjusting to their audiences, or using stylistic features like acronyms. They function within that context or environment. When these writers pass into a new system, they discover what is similar and different from what they have left behind (Rosinski 2016). Tutors, for example, may remind students that acronyms or abbreviations used in emails would be inappropriate in a research 
paper for British Studies so that writers recognize how they change when they pass between systems.

Finally, genre awareness is another powerful tool to trigger transfer (Bazerman 1997, Clark and Hernandez 2011, Devitt 2007, Nowacek 2011, Reiff and Bawarshi 2011, Rounsaville 2012, Russell 1995, Wardle 2009). Because genres are not isolated items but 'typical rhetorical[ly] based action[s]' arising from 'recurrent situations' (Miller 1984: 159), examining genres and their conventions may help writers learn 'broad concepts' (Hill 2016: 81) to apply over and over to other genres or types of writing. When tutors realize the differences among genres, they are, in turn, better prepared to empower student writers (Walker 1998: 38). To prepare tutors to talk about genres during tutorials, directors can ask their tutors to create a 'disciplinary snapshot' (Nowacek 2011: 138) of the types of writings in their own fields. Then, in a staff meeting, tutors can report about writing in their disciplines (Devet 2015). Tutors also need to develop a metaawareness of genres: seeing that some features are overarching between writings so that there can be similar 'ways of knowing' (Carter 2007: 393) or what is known as a "metagenre." Metagenre can be illustrated by considering two weekend athletes who may work out differently: one runs ten miles while the other lifts weights. Though the details of the exercise program vary, the over-arching pattern or metagenre is developing muscles and possibly losing weight (Devet 2015: 135). To develop tutors' genre awareness, trainers can describe Michael Carter's four metagenres underlying most writings: 'problem-solving' (used in Food Science and Engineering); 'research from sources' (History, English, Religious Studies); 'empirical inquiry' (Political Science, Natural Sciences); and 'performance' (Art and Design, Communication) (Carter 2007: 394). A literary analysis of Hamlet's soliloquies is similar to a History paper on the Russian Revolution because both use 'research from sources'. By knowing these metagenres, tutors can then encourage students writers to look for connections, perhaps by asking such questions as 'What topics, ideas, questions does the genre address?' or 'How are the texts in this genre structured?' or 'What actions does this genre help make possible?' (Devitt 2007: 224-225). Tutors are demystifying the writing process by helping students see links between writings. Another means to train tutors in genre awareness is to have them create a handout about writing in their fields or to interview professors about types of writing in their disciplines (Nowacek 2011: 138-139, Walker 1998: 35). My center, for instance, has handouts on how to write papers in different fields (History, Biology, Political Science), all based on the tutors' investigating the writing in their majors. Doing this work crystallizes for tutors disciplinary differences and similarities, key points of genre awareness that enable tutors to guide students to see how what students know about one genre (a History paper) can be adjusted for a different one (a Facebook page) (Nowacek 2011: 68). Being "genre aware," then, makes tutors better suited to motivate student writers to see connections between writings.

\section{Real World Examples of Transfer in Tutoring Sessions}

Although the categories - content, prior knowledge, reflection, dispositions, context, and genres - do overlap, Writing Studies' analysis of transfer provides tutors (whether working with L1 or L2 students) with ways to categorize the need for transfer as it arises in tutorials (Hill 2016). Tutors should be trained to look for the categories during their sessions so they can point out to students how to transfer.

\section{Transfer for L1 Writers}

Here is an example where a session demonstrates how a tutor can apply prior knowledge, genre awareness, and reflection to encourage transfer. A student had printed out a book review for a novel she had read in an advanced English course. The student was confused; she had been taught that no matter the writing, a thesis always appears at the end of the first paragraph. When she was unable to locate the review's thesis, she asked her tutor if the thesis was the last sentence in the review's first paragraph. Reading the review, the tutor located the thesis seven or eight paragraphs into the writing. When the tutor pointed out the thesis, the student became disconcerted because the review presented a thesis so 'late' in the document, going against all she had learned. 
This client was using her prior knowledge, engaging in low road transfer, automatically applying what she had learned in her composition classes: a thesis always appears at the end of a document's first paragraph. So, she was 'reluctant to dislodge what has already been cemented, add[ing] the new information to the old, regardless of fit' (Qualley 2016: 89). She was a 'border guarder' (Reiff and Bawarshi 2011: 314), applying to all her writings only one strategy. She was, in addition, being unmindful (not reflective) about how academic writings are usually not the same. She was also unaware of genre differences, not realizing a classroom essay differs from a professional book review. The academic tutor, however, recognized how prior knowledge, genre awareness, and lack of reflection hindered the student's writing process, so the tutor invited transfer. She explained to the student that various genres (book reviews) handle writing in different ways from classroom formula essays. The tutor also encouraged the client to reflect on these differences, being aware of discourse communities and their requirements. By discussing genre and encouraging reflection, the academic tutor established an environment for transfer to occur. As the student later reported, 'My tutor helped me to broaden my mind and to think more intelligently.'

Another example illustrates how tutors can use genres and dispositions to trigger a student's need to transfer. A computer science major, with a goal of eventually becoming a professor in her field, was applying to graduate school. To gain admission, she had brought to the center a draft of her personal statement. This statement merely listed her impressive achievements (software designs, conference proposition, published article); it did not argue how these achievements made her worthy for graduate-level work, a key goal for the genre of personal statement. The tutor needed to help the student see that listing achievements may work in a résumé, but not in an essay for graduate school admittance where the writer must 'sell' herself. So, the academic tutor explained the genre of personal statements. As a coach or mentor, the tutor also noticed the student's disposition (attitude) about her achievements was extremely self-effacing, an attitude that runs counter to the 'selling tone' needed for the genre. Because the client's disposition or 'habitus' (Bourdieu 1991: 12) was hindering her writing, the tutor addressed the student's 'self-efficacy' (Driscoll and Wells 2012, Bandura 1982) or belief in one's self to achieve a goal. The tutor gave the client a pep talk about how much the student had achieved, encouraging her to see herself as one who could, indeed, get accepted into a graduate program. In a sense, the tutor's role, following Beach, was to foster a 'consequential transition', where the student deliberately reflected on herself or her 'social position' so she could 'link [her] identity with knowledge propagation' (2003: 42). Transfer could, then, take place.

Tutors who know about rhetorical content, genres, and prior knowledge can also foster an atmosphere for transfer during a tutorial. A psychology student in an upper division course said his professor did not like how the student's paper had referenced only class lectures, not published articles. The student felt he was being asked to cater just to his professor's wishes. The tutor, however, stressed the genre in which the student was writing (a scholarly essay) should reference scholars in order to situate the student's argument in the field's ways of thinking. It is part of the genre for a psychology paper and, in fact, academic writing in general. Then, the tutor addressed the role of audience in rhetorical situations. Tapping into the students' prior knowledge, she asked the student writer if he posted Facebook entries the same way for his mother and for his friends. In other words, the tutor pointed out how the student writer adjusted to the needs of different audiences, as the writer should do for his scholarly paper in psychology. The tutor had established an atmosphere for transfer. The student evaluated the session, with, 'I can write more academically than I could before.'

\section{Transfer for L2 Writers}

Though working with L2 students presents its own challenges, it is yet another opportunity for tutors to encourage transfer. One area for recognizing the need for transfer is that of the dispositions of L2 (multilingual) writers. L2 writers already have an identity shaped by having learned their own languages; after all, 'writing enacts and creates identities and ideologies' (Adler-Kassner and Wardle 2015: 48). Now, aiming for a different language, multilingual students are again being framed by a new one. For instance, a student was not accustomed to writing an American business memo; she resisted having to be brief and to the point since her home language encouraged writing long sentences. The tutor was mindful that the student was 
a boundary guarder, not wanting to change how her language had shaped her. So, the tutor acknowledged the student's first language but emphasized the need to shift to a new language system with its own needs and methods. Thus, knowing what the L2 is experiencing makes tutors more mindful of what may be interfering with transfer (Hill in press).

Awareness that 'writing is informed by prior experience' (Adler-Kassner and Wardle 2015: 54) also helps tutors be more sensitive to the multiple needs of $L 2$ writers and thus to foster transfer. While these writers have learned to write in their own languages, they now are actively trying to see how to use that 'learned knowledge in a new language' (DePalma and Ringer 2011: 135). Tutors can solicit information to understand the L2's knowledge. For instance, when a tutor could not discover a thesis statement anywhere in a students' writing, she asked the multilingual student about the role of a thesis in the student's first language. The student explained her language rarely presents a thesis. This information helped the tutor who then described how Western rhetoric, especially in the academy, usually expresses a thesis. As one student said, 'Since I am an exchange student, I now understand better what teachers expect about the American writing style.'

Reflection is another valuable tool tutors can use to help L2 students. Tutors should be trained to realize that 'writers' histories, processes, and identities vary' (Adler-Kassner and Wardle 2015: 52); that is, multilingual writers possess different backgrounds. To handle so many differences, tutors may see multilingual writers as 'informed novices' (DasBender in press) who have rhetorical knowledge about their first languages but without enough experience, yet, to cross the thresholds into writing in another language (DasBender in press). Tutors, in turn, are 'expert outsiders' (Nowacek and Hughes 2015: 181). That is, tutors may be experienced in tutoring, but they are probably not experts in the multilinguals' writing styles, subject matter, or writing practices (DasBender in press). With this perception (tutors as expert outsiders and students as informed novices), tutors can ask L2 students (the informed novices) to reflect on 'what problems they had encountered as they did the writing, what strategies they might have used to solve the problems, and what they learned about writing and about themselves' (DasBender 2016: 284). Reflection, then, may help foster transfer for L2 writers. Of course, it is true that 'any claim about successful transfer is highly situational, context-dependent, and therefore unsuited to broader generalizations about transfer' (DasBender 2016: 281); however, tutors are uniquely situated for considering dispositions, prior knowledge, and reflection as ways to help L2 writers with transfer.

\section{Conclusion}

Admittedly, fostering transfer is difficult. First, just trying to ferret out the skills being used (or not used) by students is hard, as Elizabeth Wardle metaphorically explains: 'I suggest that focusing on a limited search for "skills" is the reason we do not recognize more evidence of 'transfer'; we are looking for apples when those apples are now part of an apple pie' (2007: 69). Then, too, student writers themselves may pose problems. As they grapple with new concepts about writing, they may be reluctant to let go of strategies for new writing situations. After all, inherent to transfer is 'the potential for disruption and transformation' (Leonard and Nowacek 2016: 256) of what student writers have clung to as they try to advance in their academic careers. However, transfer may be enabled when tutors focus on asking 'students to engage in activities that foster the development of metacognitive awareness, including asking good questions about writing situations and developing heuristics for analyzing unfamiliar writing situations' (Anson and Moore 2016: 9). Tutors should be trained to look for content, prior knowledge, dispositions, reflection, context, and genres so that they can identify moments in tutorials where they may point students in the direction of transfer. Once tutors categorize what may be occurring in the tutorials, they can do their work more effectively, creating a space for transfer and inviting transfer to occur. Doing so demonstrates that tutors can enhance students' acquisition of academic skills. 


\section{References}

Adler-Kassner, L., and Wardle, E. (2015) Naming What We Know: Threshold Concepts of Writing Studies. Logan: Utah University Press

Ambrose, S. A., Bridge, M. W., DiPietro, M., Lovett, M. C., and Norman, M. K., (eds.) (2010) How Learning Works: Seven Research-Based Principles from Smart Teaching. San Francisco: Jossey-Bass

Anson, C. M., and Moore, J. L. (2016) 'Introduction'. in Critical Transitions: Writing and the Question of Transfer. [online] ed. by Anson, C. and Moore, J. Fort Collins: WAC Clearinghouse/University Press of Colorado, 3-13. available from <http://wac.colostate.edu/books/ansonmoore> [1 September 2016]

Bandura, A. (1982) 'Self-efficacy Mechanism in Human Agency'. American Psychologist 37 (2), 122-147. DOI: 10.1037/0003-066x.37.2.122

Bates College (2017) How to Write a Paper in Scientific Journal Style and Format. [online] available from <http://abacus.bates.edu/ ganderso/biology/resources/writing/ HTWtoc.html> [6 March 2017]

Bazerman, C. (1997) 'The Life of Genre, The Life of the Classroom'. in Genre and Writing: Issues, Arguments, Alternatives. ed. by Bishop, W., and Ostrom, H. Portsmouth: Boynton/Cook

Beach, K. (2003) 'Consequential Transition: A Developmental View of Knowledge Propagation Through Social Organizations'. in Between School and Work: New Perspectives on Transfer and Boundary-Crossing. ed. by Tuomi-Gröhn, T. and Engeström, Y. Bingley: Emerald Group, 39-61

Beaufort, A. (2012) 'College Writing and Beyond: Five Years Later'. Composition Forum [online] 26. available from <http://composititionforum.com/issue/26/college-writing-beyondphp> [20 February 2018]

Bergman, L. S. and Zerpernick, J. S. (2007) 'Disciplinarity and Transference: Students' Perceptions of Learning to Write'. WPA: Writing Program Administration 31 (1-2), 124149

Bourdieu, P. (1991) Language and Symbolic Power. ed. by Thompson, J.B. translated by Raymond, G. and Adamson, M. Boston: Harvard University Press

Bransford, J. D., Brown, A. L., and Cocking, R. R., (eds.) (2000) How People Learn: Brain, Mind, Experience, and School. Washington, D.C.: National Academy Press

Brent, D. (2011) 'Transfer, Transformation, and Rhetorical Knowledge: Insights from Transfer Theory'. Journal of Business and Technical Communication [online] 25 (4), 396-420. available from <http:jbt.sagepubl.com/content/25/4/396> [1 September 2016]

Cardinal, J. (2018) 'Transfer Two Ways: Options and Obstacles in Staff Education for Transfer'. WLN: A Journal of Writing Center Scholarship 43 (1-2), 2-9

Carroll, L. A. (2002) Rehearsing New Roles How College Students Develops as Writers. Carbondale: Southern Illinois University Press

Carter, M. (2007) 'Ways of Knowing, Doing and Writing in the Disciplines'. College Composition and Communication 58 (3), 385-418

Center for Engaged Learning (2013) Writing and Learning in General Education. [online] available from <https://www.youtube.com/watch?v=LoNLigC1xjg> [6 June 2015] 
Clark, I., and Hernandez, A. (2011) 'Genre Awareness, Academic Argument, and Transferability'. The WAC Journal 22, 65-78

Cleary, M. N. (2013) 'Flowing and Freestyling: Learning from Adult Students about Process Knowledge Transfer'. College Composition and Communication 64 (4), 661-687

Cousins, G. (2006) 'Threshold Concepts, Troublesome Knowledge and Emotional Capital: An Exploration into Learning about Others'. in Overcoming Barriers to Student Understanding Threshold Concepts and Troublesome Knowledge. ed. by Meyer, J. H. F. and Land, R. London: Routledge, 134-147

DasBender, G. (2016) 'Liminal Space as a Generative Site of Struggle: Writing Transfer and L2 Students'. In Critical Transitions: Writing and the Question of Transfer. [online] ed. by Anson, C. and Moore, J. Fort Collins: WAC Clearinghouse/University Press of Colorado, 277-302. available from <http://wac.colostate.edu/books/ansonmoore> [1 September 2016]

Dasbender, G. (in press) 'Boundary Crossing in the Writing Center: Threshold Concepts, Tutor Roles, and Multilingual Writing'. WLN: A Journal of Writing Center Scholarship (Digitally Edited Collection)

DePalma, M., and Ringer, J. M. (2011) 'Toward a Theory of Adaptive Transfer: Expanding Disciplinary Discussions of 'Transfer' in Second Language Writing and Composition Studies'. Journal of Second Language Writing 20 (2), 134-147

Devet, B. D. (2015) 'The Writing Center and Transfer of Learning: A Primer for Directors'. Writing Center Journal 35 (1), 117-149

Devitt, A. (2007) 'Transferability and Genres'. in The Locations of Composition. ed. by Weisser, C. R. and Keller, C. Albany: State University of New York Press, 215-227

Donahue, C. (2016) 'Writing and Global Transfer Narratives: Situating the Knowledge Transformation Conservation.' Critical Transitions: Writing and the Question of Transfer [online] ed. by Anson, C. and Moore, J. Fort Collins: WAC Clearinghouse/University Press of Colorado, 107-137. available from <http://wac.colostate.edu/books/ ansonmoore> [1 September 2016]

Downs, D., and Wardle, E. (2007) 'Teaching about Writing, Righting Misconceptions: (Re)envisioning "First-Year Composition" as "Introduction to Writing Studies"'. College Composition and Communication 58 (4), 552-584

Driscoll, D. L. (2011) 'Connected, Disconnected, or Uncertain: Student Attitudes about Future Writing Contexts and Perceptions of Transfer from First-Year Writing to the Disciplines'. Across the Disciplines [online] 8 (2). available from $<$ https://waccolostate.edu/atd/articles/driscol2011/index.cfm> [10 February 2018]

Driscoll, D. L., and Wells. J. (2012) 'Beyond Knowledge and Skills: Writing Transfer and the Role of Student Dispositions'. [online] Composition Forum 26. available from <http://compositionforum.com/issue/26/beyond-knowldge-skills.php> [3 September 2016]

Elon College (2015) Statement on Writing Transfer. [online] available from $<$ https://www.centerforengagedlearning.org/critical-transitions-writing-and-thequestion-of-transfer/elon-statement-on-writing-transfer/> [1 September 2016]

Goodlett, T. (2001) ‘Notable Tutor Quotation’. Writing Lab Newsletter 25 (5), 15 
Hall, R. M. (2017) Around the Texts of Writing Center Work: An Inquiry-Based Approach to Tutor Education. Logan: Utah State University Press

Haskell, R. E. (2001) Transfer of Learning: Cognition, Instruction, and Reasoning. San Diego: Academic Press

Hill, H. (2016) 'Tutoring for Transfer: The Benefits of Teaching Writing Center Tutors about Transfer Theory'. Writing Center Journal 35 (3), 77-102

Hill, H. (in press) 'Preparing Tutors to Facilitate Transfer: A Proposal'. WLN: A Journal of Writing Center Scholarship (Digitally Edited Collection)

Leberman, S., McDonald, L., and Doyle, S. (2006) The Transfer of Learning: Participants' Perspectives of Adult Education and Training. Burlington: Gower

Leonard, R. L., and Nowacek, R. (2016) 'Transfer and Translingualism'. College English 78 (3), 258-264

Miller, C. (1984) 'Genre as Social Action'. Quarterly Journal of Speech 70 (1), 151-167. DOI: $10.1080 / 00335638409383686$

Nelms, G., and Dively, R. L. (2007) 'Perceived Roadblocks to Transferring Knowledge from First-Year Composition to Writing-Intensive Major Courses: A Pilot Study'. WPA: Writing Program Administration 31 (1-2), 214-240

Nowacek, R. S. (2011) Agents of Integration: Understanding Transfer as a Rhetorical Act. Carbondale: Illinois University Press

Nowacek, R. S., and Hughes, B. (2015) 'Threshold Concepts in the Writing Center Scaffolding the Development of Tutors Expertise'. in Naming What We Know: Threshold Concepts of Writing Studies. ed. by Adler-Kassner, L., and Wardle, E., Logan: Utah State University Press, 171-185

Perkins, D. N., and Salomon, G. (1988) 'Teaching for Transfer'. Educational Leadership 46 (1), 22-32

Perkins, D. N., and Salomon, G. (1989) 'Are Cognitive Skills Context Bound?' Educational Leadership 18 (1), 16-25

Perkins, D. N., and Salomon, G. (2012) 'Knowledge to Go: A Motivational and Dispositional View of Transfer'. Educational Psychology 47 (3), 248-258

Qualley, D. (2016) 'Building a Conceptual Topography of the Transfer Terrain'. in Critical Transitions: Writing and the Question of Transfer [online] ed. by Anson, C., and Moore, J. Fort Collins: WAC Clearinghouse/University Press of Colorado, 69-106. available from <http://wac.colostate.edu/books/ansonmoore/> [1 Sept 2016]

Reiff, M. J., and Bawarshi. A. A. (2011) 'Tracing Discursive Resources: How Students Use Prior Genre Knowledge to Negotiate New Writing Contexts in First-Year Composition'. Written Communication 28 (3), 312-337

Rosinski, P. (2016) 'Students' Perceptions of the Transfer of Rhetorical Knowledge between Digital Self-Sponsored Writing and Academic Writing: The Importance of Authentic Contexts and Reflection'. in Critical Transitions: Writing and the Question of Transfer [online] ed. by Anson, C. and Moore, J. Fort Collins: WAC Clearinghouse/University Press of Colorado, 251-275. available from <http://wac.colostate.edu/books/ansonmoore/> [1 Sept. 2016] 
Rounsaville, A. (2012) 'Selecting genres for Transfer: the Role of Uptake in Students' Antecedent Genre Knowledge'. Composition Forum [online] 26. available from $<$ http://compositionforum.com/issue/26/prior-knowledge-transfer.php> [28 September 2018]

Rounsaville, A., Goldberg, R., and Bawarshi, A. (2008) 'From Incomes to Outcomes: FYW Student's Prior Knowledge, metacognition, and the Question of Transfer'. WPA: Writing Program Administration 32 (1), 97-112

Russell, D. (1995) 'Activity Theory and Its Implications for Writing Instruction'. in Reconceiving Writing, Rethinking Writing Instruction. ed. by Petraglia, J. Mahwah: Lawrence Erlbaum, 51-77

Smit, D. (2007) The End of Composition. Carbondale: Southern Illinois University Press.

Thorndike, E., and Woodworth, R. S. (1901) 'The Influence of Improvement in One Mental Function Upon the Efficiency of Other Functions'. Psychological Review 8 (3), 247-261

Tuomi-Gröhn, T., and Engeström, Y. (2003) Between School and Work: New Perspectives on Transfer and Boundary Crossing. Boston: Pergamon

Walker, K. (1998) 'The Debate Over Generalist and Specialist Tutors Genre Theory's Contribution'. Writing Center Journal 18 (2), 26-46

Wardle, E. (2007) 'Understanding Transfer for FYC: Preliminary Results of a Longitudinal Study'. WPA: Writing Program Administration 31 (2), 65-85

Wardle, E. (2009) "Mutt Genres" and the Goal of FYC: Can We Help Students Write the Genres of the University?' College Composition and Communication 60 (4), 765-789

Yancey, K. B. (2009) 'Re-designing Graduate Education in Composition and Rhetoric: The Use of Remix as Concept, Material, and Method'. Computers and Composition 26 (1), 4-12

Yancey, K. B., Robertson, L., and Taczak, K. (2014) Writing Across Contexts: Transfer, Composition, and Sites of Writing. Boulder: University Press of Colorado 